\title{
School + Family Community Learning Model of PE Course under COVID-19 Epidemic Situation
}

\author{
https://doi.org/10.3991/ijet.v15i18.16439 \\ Senzhao Lu \\ Nanjing University of Aeronautics and Astronautics, Nanjing, China \\ Lsz573@163.com
}

\begin{abstract}
Influenced by COVID-19 epidemic, students cannot learn PE course offline, and online live streaming becomes a main method under the epidemic situation. How to guarantee students' learning quality at home and communication among students, parents and teachers is a matter of concern. Besides, traditional PE teaching model also has many defects, and students' dependence on the teacher is strong. On this basis, the school + family community learning model was constructed in this study based on big data technique and online teaching under the COVID-19 epidemic situation. This model takes the collaboration among students, parents and teachers as the core and key, aims to improve teachers' online teaching effect and students' online learning quality, including four stages: connection stage, adaptation stage, proficiency stage and integration stage. In addition, this model was applied in $\mathrm{PE}$ teaching in combination of cooperative learning. Meanwhile, the main firstlevel evaluation indexes of the model were developed, including teaching and resource platform, infrastructure, environment and layout, IoT application, intelligent recording and playing, training scheme, intelligent control and perception. The teaching effect was verified by the questionnaire method, and the result demonstrates that the teaching model improves both teachers' online teaching capability and students' online learning quality.
\end{abstract}

Keywords-School + family community; cooperative teaching method; evaluation system; epidemic situation.

\section{Introduction}

$\mathrm{PE}$ is a required course in the education stage, and also one of the focal points of curriculum reform. PE cannot merely let students learn basic PE knowledge and build their bodies, but also make them feel teamwork spirit, cultivate their firm and persistent characters in physical exercise and let them study and grow in a comprehensive and healthy way [1]. The new-type talents with strong body and cultural quality are the indispensable main force to construct new-type infrastructure. Through the PE teaching exploration for several decades, western countries have accumulated much valuable experience. However, at present, PE course has been a weak point in school teaching in China. The setup of many PE courses aims to let 
students gain credits, and students' learning enthusiasm and initiative are far from enough. Thus, the reform of PE teaching method is extremely urgent [2].

With the rapid development of internet technology, web-based learning has become a trend. Especially under the epidemic situation, online teaching brings a new communication and teaching barrier for students, teachers and parents. Hence, school + family community learning model based on COVID-19 epidemic situation was innovatively proposed in this study. According to the influencing factors, the model takes the collaboration among students, parents and teachers as the core and key, aims to improve teachers' online teaching effect and students' online learning quality, and finally makes students, parents and teachers form a community. Besides, the cooperative teaching method was used in online PE teaching to train students' unity and sense of competition. Finally, the evaluation system of the model was constructed to effectively help assess the teaching quality. Such new teaching strategy sets up a new bridge for the communication among students, parents and teachers, in the hope of providing a new teaching method for PE teaching and brining a new enlightenment and thought for online education.

\section{State of the Art}

European and American countries attach importance to teaching method exploration in PE teaching. Western developed countries adhere to discipline management mode in PE teaching, where the development of PE discipline is sciencebased and closer to social orientation [3]. For example, the U.S. is successful in discipline management. In the U.S., 900 colleges set up PE-related specialties and guide teaching according to different teaching plans. The report issued by United States Department of Education shows that, PE-related specialties are distributed in each discipline, like communication, pedagogy, professional and technical training [4]. Meanwhile, developed countries focus on the combination of PE occupational service and PE teaching, and utilize many PE occupational service websites to guide students, which is more beneficial to students' understanding and application of knowledge [5]. Gaetano et al. [6] applied a teaching method of ecological dynamics in PE course. In such method, the coach does not need to tutor students, but establishes an environment for various kinds of learning, with the purpose of investigating the relationship among motion control theory, learning process and body knowledge. The results show that, the new teaching method contributes to knowledge mastery. SueSee et al. [7] proposed the combination of game-based teaching and inquiry-based teaching. They assumed game-based teaching and the scope of teaching style were considered to be complementary and thought such teaching method was very suitable for Australian educational environment. It deserves to be promoted.

Looking back to the development history of PE teaching in China, it has been influenced by western sports thought, without the PE idea suitable for our development. PE experience of European and American developed countries also provides enlightenments and solutions for PE teaching difficulties in China [8]. For the reform of PE course, Li [9] pointed out the problems in college PE teaching, such 
as insufficient attention to PE teaching and students' preference to staying in dormitories and underscored the necessity of $\mathrm{P}$ teaching reform. Cen et al. [10] studied foreign methods of PE teaching reform and considered domestic educational reform should start from 4 aspects: educational paradigm change, disciplinary knowledge transformation, teaching mode exploration and students' ability extension. With the development of internet, many scholars combined online teaching to put forward new teaching and learning modes under the epidemic situation. Zhou [11] used Xuexitong APP as a new teaching medium to construct online-offline gymnastics teaching model, which improved gymnastics learning experience. Zhang [12] also considered it necessary to pay more attention to the effect of new techniques on the improvement of teaching quality and make the best of smart classroom and mobile APPs to enhance teaching innovation. To sum up, this study proposed the school + family community teaching model under the epidemic situation, with the aim of bring new teaching experience for students through online education and cooperative teaching method and applying it in PE course.

\section{Specific Application of School + Family Community Teaching Model Under the Epidemic Situation}

\subsection{Application of cooperative teaching method in online PE teaching}

The online PE teaching model based on cooperative teaching method is a new teaching model, which gives corresponding learning goals, methods and contents according to the degree of students' physical and mental development, skill mastery degree and their learning abilities and allows students to carry out cooperative learning in online classroom. In the process of cooperative learning, students determine their duties in the team and assist team members in completing tasks. In the whole process, students' interpersonal skills are not merely trained, but also their sense of team assistance and team competition is cultivated. Online PE teaching model based on cooperative teaching method is shown in Fig.1, mainly including the following stages: cooperative learning preparation, cooperative learning, inter-group exchange, reflective cooperative learning, and summarization \& comment.

Before cooperative learning, the teacher needs to help students determine corresponding learning goals according to the teaching content, and show the set scenes, rules, requirements and notes of cooperative learning via the online system. Besides, the teacher may make corresponding animations for dynamic explanation to add classroom interest and mobilize students' enthusiasm. 


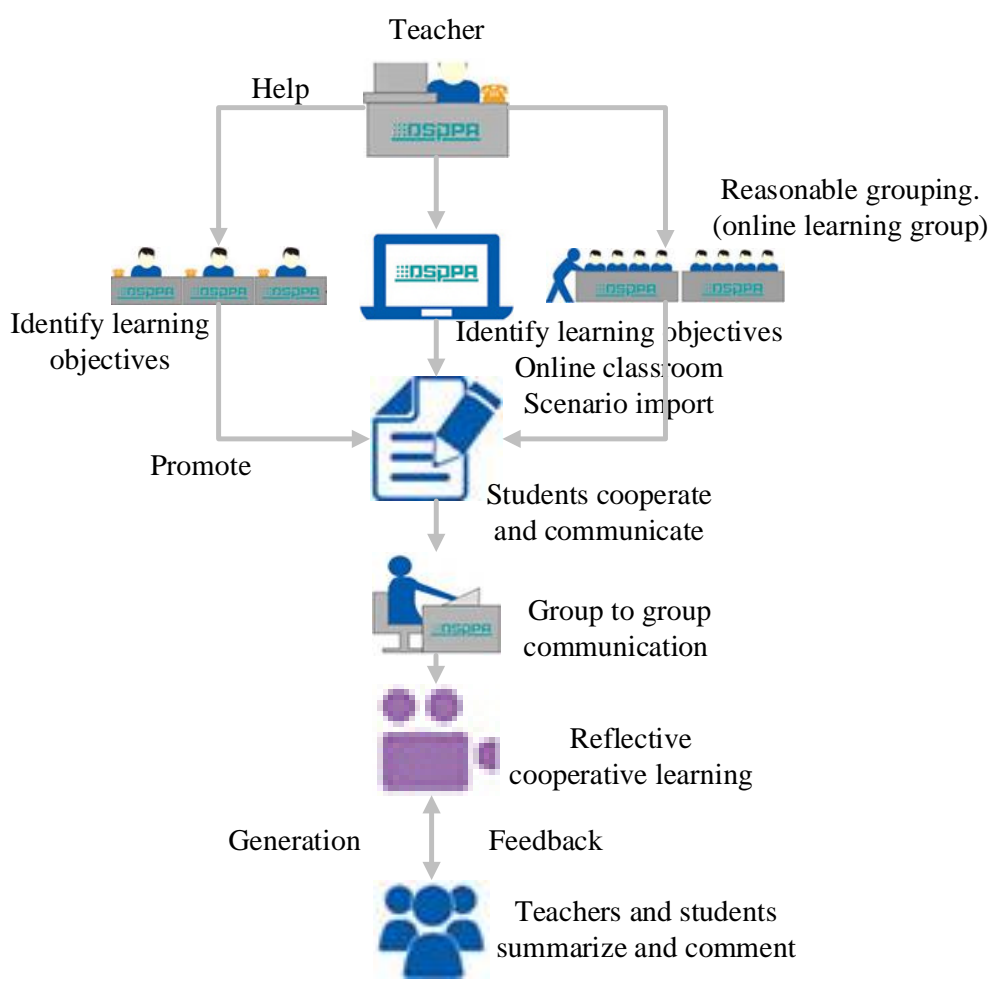

Fig. 1. Process of online PE teaching model based on cooperative teaching method

Finally, the teacher classifies the students into multiple online learning groups based on their gender and skill mastery ability. In the stage of cooperative learning exchange, students discuss online how to accomplish the tasks according to the set goals, develop corresponding plans and practice according to the plans. After intergroup cooperative learning, each group shows respective results and forms a competitive relation, which enhances students' interactivity. Then, students rethink their methods and the cooperative process in the group, absorb advantages of other teams and improve their skills. In the end, the teacher evaluates students' cooperation and group results through the online video monitoring and playback. Students comment each other to find out excellent individuals and finally get group scores and individual scores.

\subsection{Design of school + family community learning model in PE teaching}

Community frame model: Under the school + family community learning model, teachers' online teaching quality and students' online learning quality will be influenced by multiple factors, including students' autonomous learning ability, teachers' online teaching quality, parents' supervision and cooperation, the support of administrative department for education, organization and management of schools, 
selection of learning resources, help of teaching instruction department, stability of information environment and technical support. To make teachers' online teaching more efficient and improve students' online learning quality, students, parents and teachers should cooperate with each other to form a community. The school + family community model is shown in Fig.2.

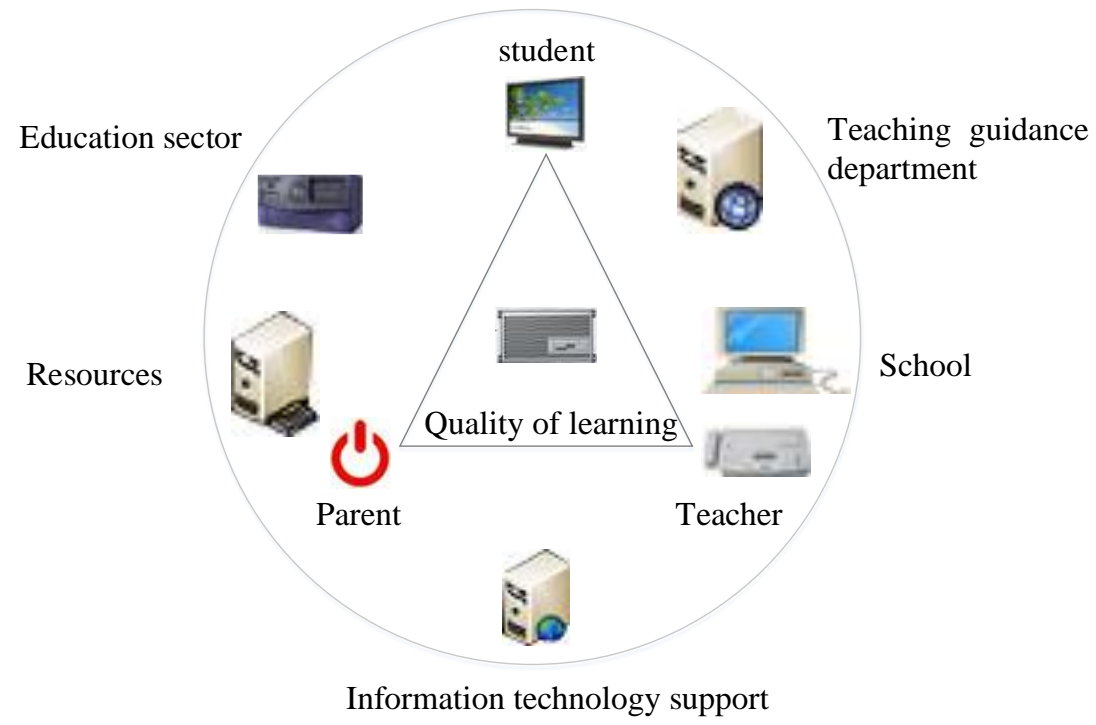

Fig. 2. School + family community model

The school + family community model is based on the background of COVID-19 epidemic. According to the influencing factors, the model takes the collaboration among students, parents and teachers as the core and key and aims to improve teachers' online teaching effect and students' online learning quality. In the model, students occupy the dominate position in family learning; the teacher's online professional guidance dominates students' online learning; parents create learning atmosphere for students' learning at home and play a supervision role; the education department provides online teaching equipment and develop relevant management measures according to the epidemic situation, encourage the implementation of online teaching and play the guiding, management and supervision role; as an important implementation unit of online teaching during the epidemic, the school should make a plan conforming to the actual situations of the school, feed the problems of online teaching to the relevant educational department in time and assist teachers in solving problems. The teaching guidance department provides online teaching guidance in multiple aspects, help teachers be familiar with the online teaching model and drive the effective implementation of online teaching. Information technology supporting personnel train teachers to make them familiar with tool operation, who provides an important guarantee for online teaching. None of the above factors is dispensable, and they cooperate with each other and present dynamic development with time, as shown in the dotted line of Fig.3.2. 
Community frame development: Community frame development mainly experiences four stages, as shown in Fig.3.

In the connection stage, the teacher is in the passive state, and less interacts with students and parents. Besides, the course arrangement is single. Students learn passively, and are strange to learning environment, with low interaction enthusiasm. Parents are not familiar with such model, and some even doubt it, so their supervision of students is not scientific.

In the adaptation stage, teacher's interactions with students and parents increase, and the community is gradually established. Teachers start to be familiar with system use and adjust course design. Students start to be familiar with online learning and interact with teachers. Under the teacher's guidance, parents supervise students more scientifically.

In the proficiency stage, teachers, students and parents can divide the work reasonably and cooperate well. Teachers' passive teaching becomes active. Besides, teachers carry out course design, add interaction tasks and course interest, and promote students' independent study. Students increase interactions with teachers and jointly consult the learning plan with teachers. Meanwhile, they learn more independently and experience learning joys.

With the improvement of students' online learning ability, the enhancement of students' autonomous learning ability and parents' tacit cooperation, online teaching enters the integration stage in which teachers can efficiently conduct online teaching and share experience with other teachers, with the flexibly teaching methods. In the meantime, students form the autonomous learning ability, manage themselves, learn to rethink and own creative thinking.

Construction of school + family community learning model in PE course: We briefly described multiple factors influencing online learning and online teaching during the epidemic, constructed the school + family community and analyzed its development process. To better promote it, the framework of school + family community learning model was constructed in this section by combining PE course teaching and applying cooperative teaching method (as shown in Fig.4.). The whole model takes the big data platform and online teaching system as the bottom support, and the school + family community as the core for online and offline learning activities to further promote students' study and growth.

The front-end diagnosis and preparation are the analysis work before the whole teaching activity. The administrative department for education interprets the policy for the epidemic and analyzes epidemic and the attainments of students and teachers. Technical personnel make statistics of teaching resources and platforms available for the development of teaching programs and plans conforming to actual conditions. Meanwhile, students, parents and teachers should analyze students' learning environment at home and learning situations for the development of learning plans. 


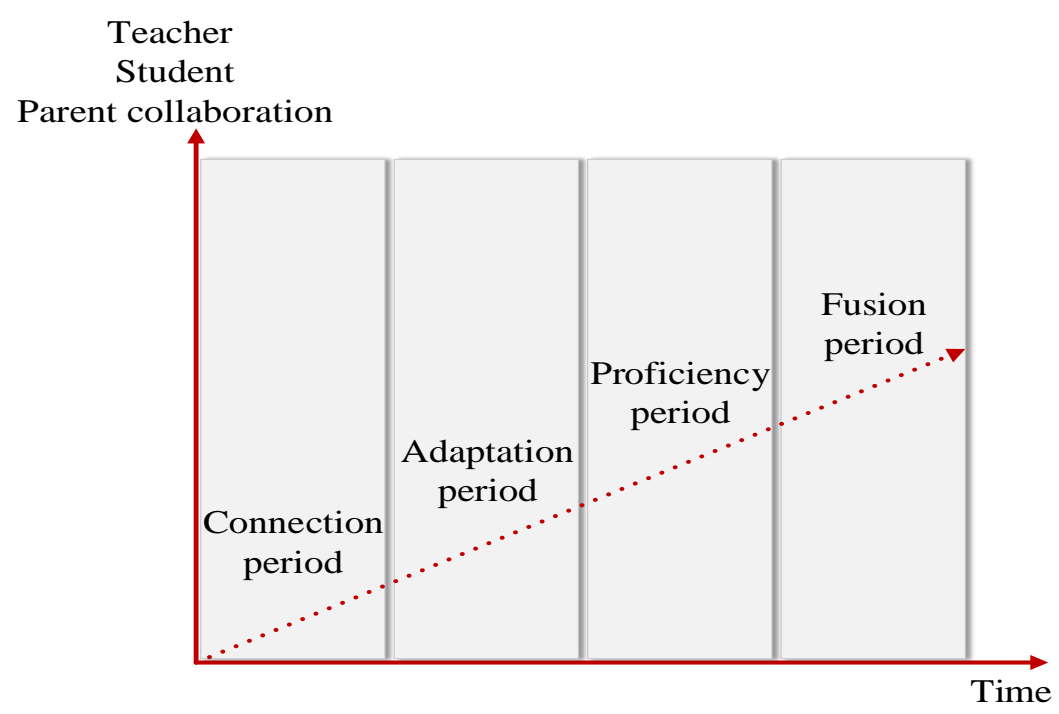

Fig. 3. School + family community development

Online education and learning of school + family community: After the school + family community is constructed, the teacher publishes the teaching program and plan through the online platform, and parents and students understand the learning tasks and purposes through the platform. The teacher chooses rational teaching resources and conducts teaching design according to the teaching content. In the teaching activity, the teacher adopts cooperative teaching method for PE course, firstly creates the design environment, then classifies online groups and organizes students' cooperation and exchange. Students in the group show their own ideas through the platform, and the teacher supervises students through the online video and answers students' questions in time.

Students' learning at home: Students' learning at home includes online and offline learning. Students determine their learning goals according to their learning situations, complete learning tasks through independent material consulting or online discussions with the teacher, classmates and parents, carry out self-evaluation and self-reflection, reconstruct their knowledge hierarchy, absorb others' advantages and improve their ability and value. 


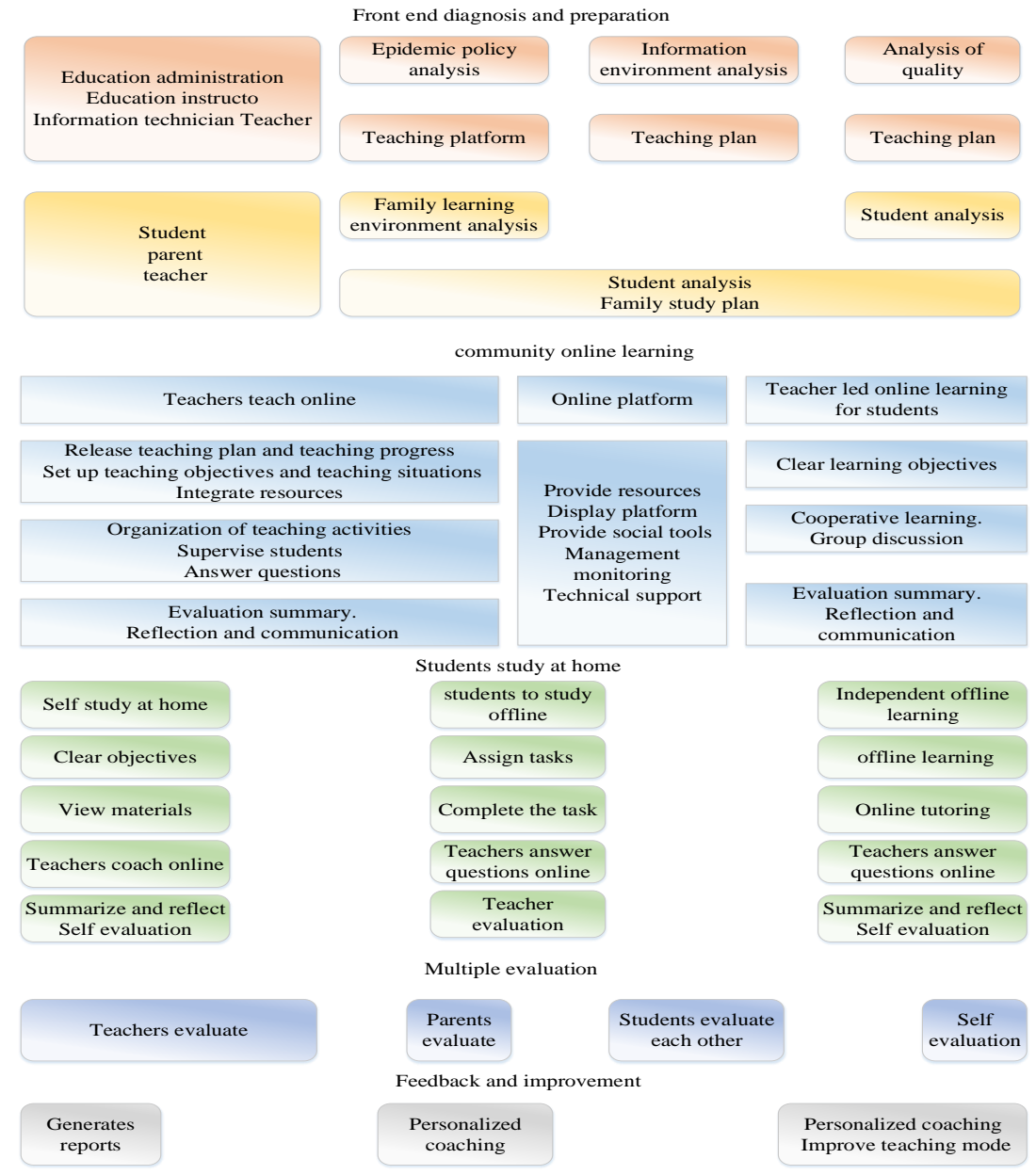

Fig. 4. Framework of school + family community learning model

Multi-evaluation: Multi-evaluation combines the evaluation from teachers, students and parents as well as self-evaluation. The teacher conducts quantitative evaluation of students with the help of statistical data of the big data platform. Parents assess students through supervising and observing their learning process. Students conduct self-evaluation through comparison with others and reflection.

Feedback and improvement: On the one hand, the individualized reports will be generated through the platform so that the teacher can provide individualized tutoring; on the other hand, the problems in the learning and teaching process should be fed back to relevant departments and personnel, and relevant help should be provided for teachers. Meanwhile, teaching design should be improved to make classroom quality more efficient. 


\subsection{Construction of evaluation system for school + family community learning model in PE course}

Preliminary evaluation indexes: The internal relations of evaluation indexes are close, and they will not be repeated. To evaluate the school + family community learning model more conveniently, main first-level evaluation indexes for the model were developed preliminarily, including teaching and resource platform, infrastructure, environment and layout, IoT application, intelligent recording and playing, training scheme, intelligent control and perception, software and hardware tools and mobile terminal as well as virtual simulation. The evaluation indexes will be further analyzed and determined as below.

\section{Modification and determination of evaluation indexes}

Consulting experts' selection: The first step to evaluate the school + family community learning model is to consult experts' selection. In this study, dozens of front-line teachers with rich experience, experts in educational technology industry and senior corporate technical experts were chosen. Artificial sampling method was applied to make expert sample coverage more uniform. The details of experts are shown in Table 1.

Table 1. Category and experience of experts

\begin{tabular}{|c|c|c|c|c|c|}
\hline $\begin{array}{l}\text { Expert } \\
\text { code }\end{array}$ & Category & Relevant experience & $\begin{array}{l}\text { Expert } \\
\text { code }\end{array}$ & Category & Relevant experience \\
\hline \multirow{2}{*}{$\begin{array}{l}\mathrm{ZJ}_{1} \\
\mathrm{ZJ}_{2}\end{array}$} & \multirow{3}{*}{$\begin{array}{l}\text { Front-line } \\
\text { teachers with } \\
\text { rich experience }\end{array}$} & $\begin{array}{l}\text { Five-year teaching } \\
\text { experience }\end{array}$ & \multirow{2}{*}{$\begin{array}{l}Z_{6} J_{6} \\
Z J_{7}\end{array}$} & \multirow{3}{*}{$\begin{array}{l}\text { Experts in } \\
\text { educational } \\
\text { technology } \\
\text { industry }\end{array}$} & \multirow{3}{*}{$\begin{array}{l}\text { Assess teaching model } \\
\text { development }\end{array}$} \\
\hline & & $\begin{array}{l}\text { Three-year teaching } \\
\text { experience }\end{array}$ & & & \\
\hline \multirow{3}{*}{$\begin{array}{l}\mathrm{ZJ}_{3} \\
\mathrm{ZJ}_{4} \\
\mathrm{ZJ}_{5}\end{array}$} & & $\begin{array}{l}\text { One-year teaching } \\
\text { experience }\end{array}$ & \multirow{3}{*}{$\begin{array}{l}\mathrm{ZJ}_{8} \\
\mathrm{ZJ}_{9} \\
\mathrm{ZJ}_{10}\end{array}$} & & \\
\hline & \multirow{2}{*}{$\begin{array}{l}\text { Experts in } \\
\text { educational } \\
\text { technology } \\
\text { industry }\end{array}$} & $\begin{array}{l}\text { Patriciate in teaching } \\
\text { model development }\end{array}$ & & \multirow{2}{*}{$\begin{array}{l}\text { Senior } \\
\text { corporate } \\
\text { technical } \\
\text { experts }\end{array}$} & $\begin{array}{l}\text { Teaching model } \\
\text { development for } 3 \text { times }\end{array}$ \\
\hline & & $\begin{array}{l}\text { Organize teaching } \\
\text { model development }\end{array}$ & & & $\begin{array}{l}\text { Teaching model } \\
\text { development for } 5 \text { times }\end{array}$ \\
\hline
\end{tabular}

Determination of evaluation indexes: To determine evaluation indexes in a scientific and objective way, smart classroom evaluation method was adopted in this study to analyze 9 preliminary first-level evaluation indexes in Section 3.3.1. Next, the evaluation indexes will be further verified according to the above formulas and analysis:

The evaluation index questionnaire is developed and filled in by dozens of experts. The survey results are collected.

The survey results of evaluation indexes are shown in Table 2. The index elimination coefficient is figured out according to the above formula, $Z=\bar{Y}-\sum S D=12.39-6.33=6.06$. According to the line of comprehensive index (Y), the comprehensive indexes of both IoT application and virtual simulation are less than 6.06 , the two should be removed from the preliminary 9 evaluation indexes. 
Table 2. Statistical analysis of survey results

\begin{tabular}{|l|c|c|c|c|c|c|c|c|c|}
\hline \multicolumn{1}{|c|}{ Index } & $\mathbf{1}$ & $\mathbf{2}$ & $\mathbf{3}$ & $\mathbf{4}$ & $\mathbf{5}$ & $\mathbf{6}$ & $\mathbf{7}$ & $\mathbf{8}$ & $\mathbf{9}$ \\
\hline Mean (M) & 4.7 & 4.4 & 4.3 & 4.5 & 4.3 & 4.5 & 2.2 & 2.6 & 4 \\
\hline Standard deviation (SD) & 0.5 & 0.5 & 0.64 & 0.67 & 0.64 & 0.67 & 1.33 & 0.66 & 0.77 \\
\hline Full mark ratio (M) & 0.7 & 0.3 & 0.4 & 0.6 & 0.4 & 0.6 & 0.1 & 0 & 0.3 \\
\hline Coefficient of variable (CV) & 0.1 & 0.11 & 0.15 & 0.15 & 0.15 & 0.15 & 0.6 & 0.26 & 0.19 \\
\hline Comprehensive index (Y) & 33.7 & 11.86 & 11.55 & 18.11 & 11.55 & 18.11 & 0.36 & 0 & 6.2 \\
\hline
\end{tabular}

Based on the above process, 7 first-level evaluation indexes were determined in this study. Similarly, the second-level evaluation indexes were determined. The consultant expert questionnaire was applied, and the detailed process is not described here. Finally, 26 second-level evaluation indexes were determined. The evaluation criterion system of school + family community learning model is also generated, as shown in the following figure:

The structural system contains three layers: target layer A, criterion layer B and criterion layer $\mathrm{C}$. The target layer A represents the final satisfaction for the system, and it is also our ultimate purpose for the construction of system evaluation criterion. The criterion layer B contains 7 first-level evaluation indexes determined in Section above. The criterion layer $\mathrm{C}$ includes 26 second-level evaluation indexes. In the end, through the scores of these indexes, the construction of school + family community can be assessed objectively and scientifically.

Determination of evaluation index weight: We finally determined the hierarchical structure model of school + family community learning model, including 7 first-level indexes and 26 second-level indexes. Next, the results of expert survey questionnaire will be analyzed from another dimension to determine the weight ratio of each evaluation index. The analysis method is as below: carrying out data operation for the evaluation results of dozens of experts, constructing the judgment matrix of each expert, testing the result consistency and finally solving the mean for the weight results, namely the final result. For the simplified analysis, ZJ1 was taken for example and the detailed process is as below:

$\mathrm{ZJ} 1$ structure matrix is expressed with A, and the results are shown in Table 3.

Table 3. Structure matrix

\begin{tabular}{|l|c|c|c|c|c|c|c|}
\hline \multicolumn{1}{|c|}{ Evaluation index } & $\mathbf{1}$ & $\mathbf{2}$ & $\mathbf{3}$ & $\mathbf{4}$ & $\mathbf{5}$ & $\mathbf{6}$ & $\mathbf{7}$ \\
\hline 1 Infrastructure & 1 & 6 & 4 & $1 / 3$ & 3 & 5 & 7 \\
\hline 2 Environment and layout & $1 / 6$ & 1 & $1 / 4$ & $1 / 7$ & $1 / 5$ & $1 / 3$ & 3 \\
\hline 3 Intelligent recording and playing & $1 / 5$ & 4 & 1 & $1 / 5$ & $1 / 3$ & 3 & 5 \\
\hline 4 Teaching and resource platform & 3 & 7 & 5 & 1 & 4 & 6 & 8 \\
\hline 5 Intelligent control and perception & $1 / 3$ & 5 & 3 & $1 / 5$ & 1 & 4 & 6 \\
\hline 6 Software \& hardware tools and mobile terminal & $1 / 5$ & 3 & $1 / 3$ & $1 / 6$ & $1 / 4$ & 1 & 4 \\
\hline 7 Training schemes & $1 / 8$ & $1 / 7$ & $1 / 5$ & $1 / 8$ & $1 / 6$ & $1 / 4$ & 1 \\
\hline
\end{tabular}

Conduct matrix operations for matrix A, that is, multiply the data in each line of the matrix to gain vector $\mathrm{Ai}$; the result of $\mathrm{Ai}$ is

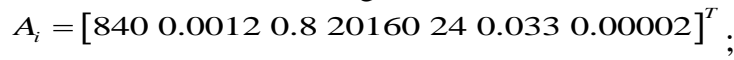


Paper-School + Family Community Learning Model of PE Course under COVID-19 Epidemic ...

Take the seventh root for vector $\mathrm{Ai}$ and get $C=\left[\begin{array}{lllllll}2.61 & 0.38 & 0.968 & 4.12 & 1.57 & 0.61 & 0.21\end{array}\right]^{T}$;

Figure out the feature vector of vector $\mathrm{C}$

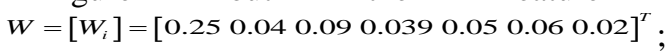

Solve the maximum feature root. Since $A W=\left[\begin{array}{llllll}1.85 & 0.267 & 0.692 .97 & 1.126 & 0.430 .16\end{array}\right]^{T}$, the maximum feature root $\lambda_{\max }=\frac{1}{n} \sum_{i} \frac{(A W)_{i}}{W_{i}}=7.55$;

Figure out the consistency index CI, $\mathrm{CI}=\frac{\lambda_{\max }-n}{n-1}=0.09$;

Solve consistency ratio $\mathrm{CR}$. Since the RI value of consistency index of the 7 thorder judgment matrix is $1.32, \mathrm{CR}=\frac{C I}{R I}=\frac{0.09}{1.32}=0.068<1$, showing the judgment matrix is consistent.

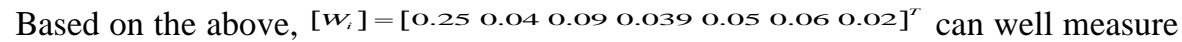
the importance degree of first-level indexes. Similarly, the second-level indexes can be analyzed.

\section{$4 \quad$ Teaching Example and Effect}

\subsection{Teaching example}

$\mathrm{PE}$ is a discipline which pays attention to practice, so the school + family community learning model was designed in this study. It can improve students' interaction and cooperative learning ability as well as interpersonal skills, and enhance students' learning initiative at home through the full integration of online mode and cooperative teaching method. The teacher turns to the role of guiding, organizing and supervising students from one-way knowledge teaching. In this study, "traditional martial arts" in PE course was chosen as the teaching content, and teaching design included three stages: before class, in class and after class. The teaching model design is shown in Fig.5. Fig6 and Fig.7 display online learning situations of school + family community learning model. 
Study before class

\begin{tabular}{|c|c|c|}
\hline Teache & $\begin{array}{c}\text { Publish online learning videos } \\
\text { Set up groups }\end{array}$ & $\begin{array}{l}\text { Monitor the learning } \\
\text { effect online }\end{array}$ \\
\hline Student & $\begin{array}{l}\text { Learn knowledge } \\
\text { Online discussion }\end{array}$ & $\begin{array}{l}\text { Work together within } \\
\text { the group }\end{array}$ \\
\hline
\end{tabular}

Live online

\begin{tabular}{|c|c|c|c|c|}
\hline \multirow[t]{2}{*}{ Teache } & $\rightarrow$ Exhibition of works & Online & \multicolumn{2}{|c|}{ Effect test } \\
\hline & Feedback & $\mathrm{Fe}$ & & Feedback \\
\hline Student & Job answers & $\begin{array}{l}\text { Online } \\
\text { learning }\end{array}$ & & $\begin{array}{l}\text { learning } \\
\text { ete test }\end{array}$ \\
\hline
\end{tabular}

Improve after class

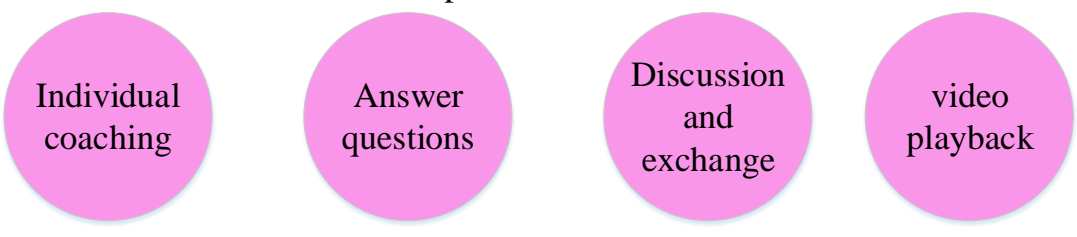

Fig. 5. School + family community learning model

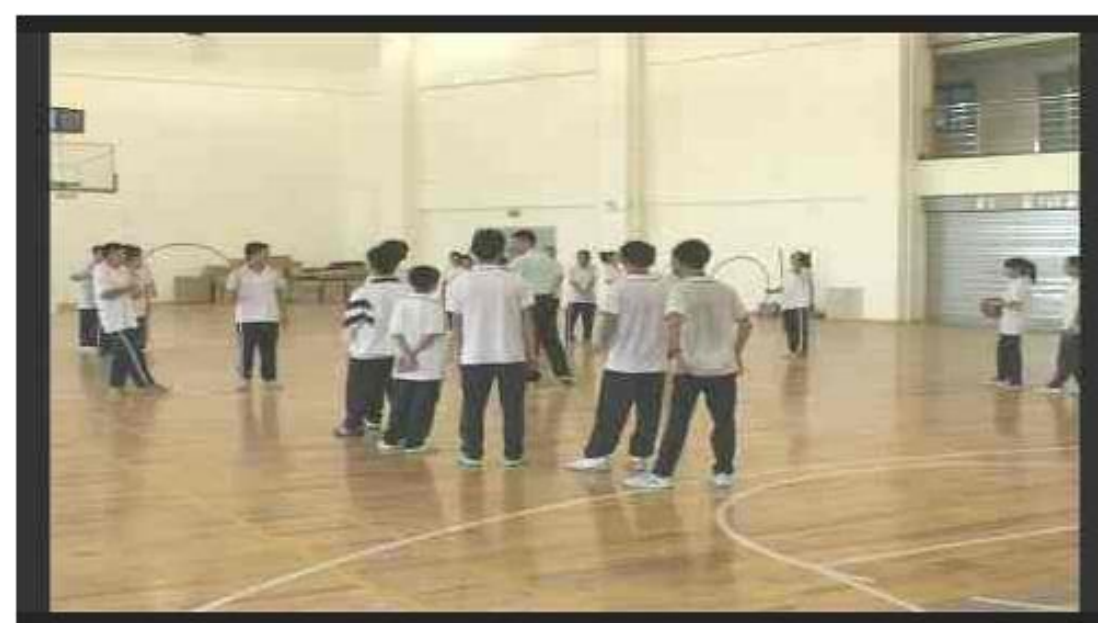

Fig. 6. Online learning screenshot I 


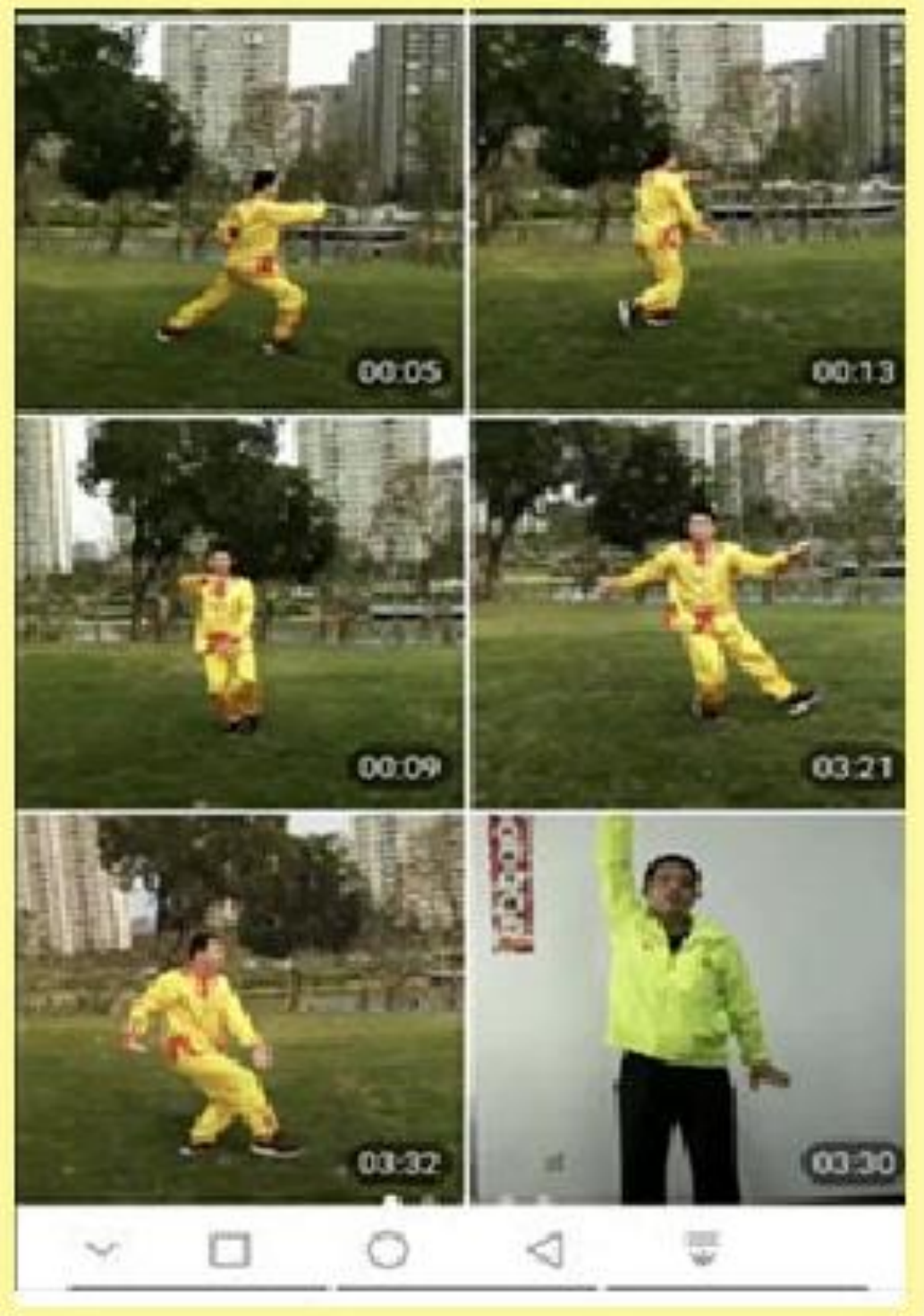

Fig. 7. Online learning screenshot II

Before class. The teacher published learning videos and documents about traditional martial arts through the online learning platform and established the online learning groups. Students learned three major characteristics of traditional martial arts through videos (regionalism, diversity and morality of martial arts). Each group chose a kind of martial arts to investigate its origin, features and development, learned cooperatively and made corresponding graphs of works. 
In class. The teacher played the clips of a film with the theme of traditional martial arts - IP Man, introduced the theme and aroused students' interest. Then, group assignments were displayed, and the teacher guided students to actively ask and answer questions, and solved students' doubts in time. In the process of group work display, students could find out their wrong understanding and correct. At the end of the course, the teacher carried put online test according to the classroom content to understand students' learning situations.

Improvement after class. For the test results of each student and students' situations fed back by the platform, the teacher conducted one-to-one individualized tutoring and solved students' doubts. Students could play back the videos for secondary study to enhance knowledge understanding and further improve their skills.

\subsection{Teaching effect}

60 students included in the online PE teaching were surveyed by the online system questionnaire, and the results are as below.

The acceptance of new learning model is shown in table 4, 51 students could accept it, and 9 could not accept it, with a high acceptance degree.

Table 4. Evaluation of teaching effect

\begin{tabular}{|l|l|c|c|}
\hline \multicolumn{1}{|c|}{ Question } & \multicolumn{1}{c|}{ Option } & n & Percent \\
\hline \multirow{2}{*}{ Can you accept the new teaching mode } & Yes & 51 & $85 \%$ \\
\cline { 2 - 4 } & No & 9 & $15 \%$ \\
\hline \multirow{2}{*}{ Whether the interaction in class is improved } & Improve & 48 & $80 \%$ \\
\cline { 2 - 4 } & Reduce & 12 & $20 \%$ \\
\hline \multirow{2}{*}{ Can you skillfully use the online teaching system } & Skilled & 30 & $50 \%$ \\
\cline { 2 - 4 } & Commonly & 11 & $18.30 \%$ \\
\cline { 2 - 4 } & Unskilled & 19 & $31.70 \%$ \\
\hline
\end{tabular}

The survey results of classroom interaction influence are shown in table 4. 48 students considered the model improved their enthusiasm and increased their interactions, while 12 students felt such model reduced their interactions.

The survey results of application proficiency for the online learning system are shown in table 4. 19 students expressed they were not very proficient in it, while 30 students could proficiently use it. The results differ greatly, which deserves to be noted. Thus, it is necessary to enhance the training for the online system and tool application to improve the efficiency.

\section{Conclusion}

Based on the background of "no stop of learning despite of class suspending", this study proposed a new teaching model for PE under the epidemic situation. The cooperative teaching method, school + family community learning model and the evaluation system of such learning model were proposed respectively. Besides, such 
new learning model was applied for PE teaching practice, and the teaching effect was verified by the questionnaire. In such model, both teachers' online teaching ability and students' online learning ability improved. Meanwhile, students' cooperative learning ability, autonomous learning ability and creativity were cultivated. The specific reasons are as below:

Firstly, the new model of PE teaching has positive influence on the improvement of students' comprehensive quality. In the traditional PE teaching method, teachers generally teach sports skills, and the teaching method is not rational enough. The PE teaching based on school + family community learning model could let students gain joys in the process of mastering sports skills, except mastery of basic sports skills, which cannot be achieved in traditional PE teaching method. New knowledge and skills can be learned and improved before class, in class and after class. In this way, students can fully understand the principle of a movement and clearly know where they may make mistakes easily and what learning methods should be chosen to enhance exercise. In this way, their learning autonomy is fully reflected and their learning initiative is also improved. Both teachers and students are more willing to accept this new teaching model.

Secondly, the new model of PE teaching can enhance interaction enthusiasm of students and teachers. Traditional PE teaching only focuses on the improvement of movement skills and test scores, thus leading to restricted improvement of students' exploration and autonomy and strong dependence on teachers. The PE teaching based on the school + family community learning model can give full play to students' subjective initiative, let students master correct technical movements and consolidate knowledge under rational guidance of teachers, which ensures students' learning effect, makes their thinking more active and plays a significant role in cultivating their creativity. Meanwhile, under such learning model, students' learning efficiency is higher, and teachers' teaching is also simplified. Besides, the interaction between the teacher and students is stronger, and the effect is better.

We also found that, due to the time limit, we had no too much time for operation technology guidance before the formal application of school + family community learning model, so some students were not familiar with the operating system of the new learning model. In the future work, how to improve online learning quality through scientific training will be further investigated.

\section{References}

[1] Landi, D., Fitzpatrick, K., Mcglashan, H. Models Based Practices in Physical Education: A Sociocritical Reflection. Journal of Teaching in Physical Education, 2016, vol. 35(4), pp. 400-411. https://doi.org/10.1123/jtpe.2016-0117

[2] Kim, S., Chang M.C. A Study on Application Method of Process-Centered Evaluation of Elementary School Physical Education : Focused on Net-Type Competition Activities. Korean Society for the Study of Physical Education, 2017, vol. 22(1), pp. 125-140. https ://doi.org/10.15831/jksspe.2017.22.1.125

[3] Cazers, G., Curtner-Smith, M.D. Robin's Story: Life History of an Exemplary American Female Physical Education Teacher. Journal of Teaching in Physical Education, 2017, vol. 
36(2), pp. 197-208. https://doi.org/10.1123/jtpe.2015-0084

[4] Mehrosh P, Xavier L, Stefan G. Addressing binding site specificities of bromodomains using an in-silico drug discovery pipeline. American Physical Education Review, 2015, vol. 73(6). pp. 23-27.

[5] Duncan, S.C., Strycker, L.A., Chaumeton, N.R. School Influences on the Physical Activity of African American, Latino, and White Girls. Journal of School Health, 2015, vol. 85(1), pp. 43-52. https://doi.org/10.1111/josh.12218

[6] Raiola, G., Tafuri, D. Teaching method of physical education and sports by prescriptive or heuristic learning. Journal of Human Sport and Exercise, 2015, vol. 10(1), pp. S337-S384. https://doi.org/10.14198/jhse.2015.10.proc1.28

[7] SueSee, B., Pill, S., \& Edwards, K. (2016). Reconciling approaches - a game centred approach to sport teaching and Mosston's spectrum of teaching styles. European Journal of Physical Education and Sport Science, vol. 2(4), pp. 69-96. https://doi.org/10.4324/978042 $\underline{9341342-7}$

[8] Merino-Marban, R., Mayorga-Vega, D., Fernandez-Rodriguez, E., Estrada, F.V., \& Viciana, J. Effect of a physical education-based stretching programme on sit-and-reach score and its posterior reduction in elementary schoolchildren. European Physical Education Review, 2015, vol. 21(1), pp. 83-92. https://doi.org/10.1177/1356336x1455094 $\underline{2}$

[9] Li, M.L., \& Ren, Y.J. A multimedia teaching model for "sports statistics" based on arcs motivation theory. International Journal of Emerging Technologies in Learning, 2018, vol. vol. 13(9), pp. 15-28. https://doi.org/10.3991/ijet.v13i09.8972

[10] Chen, Y.X., Zhang, S.W. An exploration into foreign physical education reform under the core attainment framework. Journal of Physical Education, 2018, vol. 25(1), pp. 104-109.

[11] Zhou, Y.B. Design of moodle-based podcast teaching platform for the course of aerobic gymnastics. international journal of emerging technologies in learning, 2017, vol. 12(9), pp. 95-104. https://doi.org/10.3991/ijet.v12i09.7490

[12] Zhang, J.C. Probe into the Mixed Teaching Mode Based on Smart Phone and Smart Classroom under the Background of "Internet+". Educational Research, 2019, vol. 42(4): pp. 41-42.

\section{Author}

Senzhao Lu is an association professor in the Nanjing University of Aeronautics and Astronautics, Nanjing, China (Lsz573@163.com).

Article submitted 2020-06-20. Resubmitted 2020-07-08. Final acceptance 2020-07-09. Final version published as submitted by the authors. 